\title{
Climate change projections and stratosphere-troposphere interaction
}

Article

Accepted Version

Scaife, A. A., Spangehi, T., Cubasch, U., Langematz, U., Akiyoshi, H., Bekki, S., Butchart, N., Chipperfield, M. P., Gettelman, A., Hardiman, S. C., Michou, M., Rozanov, E. and Shepherd, T. G. (2012) Climate change projections and stratosphere-troposphere interaction. Climate Dynamics, 38 (9-10). pp. 2089-2097. ISSN 0930-7575 Available at https://centaur.reading.ac.uk/31550/

It is advisable to refer to the publisher's version if you intend to cite from the work. See Guidance on citing.

Published version at: http://link.springer.com/article/10.1007/s00382-011-1080-7

Publisher: Springer

All outputs in CentAUR are protected by Intellectual Property Rights law, including copyright law. Copyright and IPR is retained by the creators or other copyright holders. Terms and conditions for use of this material are defined in the End User Agreement.

www.reading.ac.uk/centaur

\section{CentAUR}


Central Archive at the University of Reading

Reading's research outputs online 


\section{Climate Change Projections and Stratosphere-Troposphere Interaction}

Adam A. Scaife ${ }^{*}, 1$, Thomas Spangehl ${ }^{2}$, David R. Fereday ${ }^{1}$, Ulrich Cubasch ${ }^{2}$, Ulrike Langematz ${ }^{2}$, Hideharu Akiyoshi ${ }^{3}$, Slimane Bekki ${ }^{4}$, Peter Braesicke ${ }^{5}$, Neal Butchart ${ }^{1}$, Martyn P. Chipperfield ${ }^{6}$, Andrew Gettelman ${ }^{7}$, Steven C. Hardiman ${ }^{1}$, Martine Michou, Eugene Rozanov ${ }^{9}$ and Theodore G. Shepherd ${ }^{10}$.

*- adam.scaife@metoffice.gov.uk, Tel: +44 (0)1392 884056, Fax: +44 (0)1392 885681

${ }^{1}$ - Met Office Hadley Centre, Exeter, UK.

2 - Freie Universitaet Berlin, Berlin, Germany.

${ }^{3}$ - National Institute for Environmental Studies, Tsukuba, Japan.

${ }^{4}$ - LATMOS-IPSL; UVSQ; UPMC; CNRS/INSU, France

5 - University of Cambridge, UK.

${ }^{6}$ - School of Earth and Environment, University of Leeds, UK

${ }^{7}$ - National Center for Atmospheric Research, Boulder, Colorado, USA.

${ }^{8}$ - GAME/CNRM (Meteo France, CNRS), Toulouse, France.

${ }^{9}$ - PMOD/WRC and ETHZ, Davos, Switzerland.

10 - University of Toronto, Canada. 


\begin{abstract}
Climate change is expected to increase winter rainfall and flooding in many extratropical regions as evaporation and precipitation rates increase, storms become more intense and storm tracks move polewards. Here we show how changes in stratospheric circulation could play a significant role in future climate change in the extratropics through an additional shift in the tropospheric circulation. This shift in the circulation alters climate change in regional winter rainfall by an amount large enough to significantly alter regional climate change projections. The changes are consistent with changes in stratospheric winds inducing a change in the baroclinic eddy growth rate across the depth of the troposphere. A change in mean wind structure and an equatorward shift of the tropospheric storm tracks relative to models with poor stratospheric resolution allows coupling with surface climate. Using the Atlantic storm track as an example, we show how this can double the predicted increase in extreme winter rainfall over Western and Central Europe compared to other current climate projections.
\end{abstract}

Keywords: Climate Change, Europe, stratosphere, storm track 


\section{Introduction}

Current climate models predict greater mean and extreme winter rainfall in response to increasing levels of greenhouse gases (Solomon et al. 2007). This consensus is derived from state-of-the-art climate models which contain an extensive set of parametrizations to represent atmospheric, oceanic and land surface processes.

Most models used for future climate projection devote only a small fraction of their total computational cost to the stratosphere and its interaction with surface climate is often poorly reproduced in simulations of past climate (Scaife et al. 2005, Gillett et al. 2005). Similarly, while the potential sensitivity of climate projections to global horizontal resolution is widely recognised (Matsueda et al. 2009), most models used in recent IPCC projections had relatively poor vertical resolution of the atmosphere above the tropopause (Cordero and Forster 2006). Despite this, in contrast to these standard resolution models, extended atmospheric models have been produced which have a good representation of the stratosphere and mesosphere (Pawson et al. 2000, Morgenstern et al. 2010) and work is now progressing to couple these models to interactive ocean components to provide extended climate models that can be used to make projections of the effects of increasing greenhouse gases on the coupled oceantroposphere-stratosphere system (Huebener et al. 2008, Shaw and Shepherd 2008).

Here we compare climate change due to changing greenhouse gas amounts in standard climate models and vertically extended models to determine whether an improved representation of the stratosphere (and associated model changes) is likely to alter the surface climate response. While there is an enormous choice of possible climate model formulations that can not easily be distinguished on observational or theoretical grounds 
(Murphy et al. 2004, Sigmond et al. 2008) we will also use a multi-model ensemble that has been applied in other contexts (Son et al. 2008) to show that the effect of extending climate models to better represent the stratosphere is largely independent of model formulation, at least across the range of currently available models.

\section{Method: Standard and Extended Climate Models}

We analyse two climate models in detail: model 1 is the Hadley Centre Global Environmental Model (HadGEM, Martin et al. 2006, Ringer et al. 2006) and model 2 is the ECHO-G Middle Atmosphere Model (EGMAM, Huebener et al. 2007). The "standard" versions of these models have a vertical domain with limited stratospheric resolution. The "extended" versions of the models represent the full depth of the middle atmosphere as described below.

Standard model 1 (HadGEM) has 38 levels from the surface to $\sim 40 \mathrm{~km}$ altitude. Extended model 1 has identical levels up to level 30 near the tropopause and a further 30 levels to around $84 \mathrm{~km}$ near the mesopause. Horizontal resolution is $1.25^{\circ}$ Latitude by $1.875^{\circ}$ Longitude in both cases. Physical parametrizations are similar in the models but extended model 1 incorporates a shorter timestep and additional gravity wave drag to obtain realistic simulations of the stratosphere (Scaife et al. 2002). Extended model 1 simulates near surface control climate close to that of standard model 1 (Fig.1). The models were run under preindustrial greenhouse gas conditions and potential future conditions with four times the mixing ratio of carbon dioxide. Ozone levels were kept constant in the simulations. Extended model simulations were run for 30 years and standard model simulations were run for 24 years for both $1 \mathrm{xCO}_{2}$ and $4 \mathrm{xCO}_{2}$. Both models were driven by ocean surface conditions from $1 \mathrm{xCO}_{2}$ and $4 \mathrm{xCO}_{2}$ simulations with a coupled ocean-atmosphere version of the standard model. 
Standard model 2 is ECHO-G (Legutke and Voss 1999) and has 19 levels from the surface to $\sim 30 \mathrm{~km}$ altitude. Extended model 2 has 25 levels from the surface to $\sim 30 \mathrm{~km}$ and 14 further levels to $\sim 80 \mathrm{~km}$ in the upper mesosphere (Huebener et al. 2007). Horizontal resolution is $\mathrm{T} 30\left(\sim 3.75^{\circ}\right)$. Physical parametrizations are similar in the models but extended model 2 incorporates additional (different to extended model 1) spectral gravity wave drag (Manzini and McFarlane 1998). Huebener et al (2007) showed that extended model 2 simulates near surface control climate close to that of standard model 2. Extended model 2 was run in coupled ocean-atmosphere mode from a pre-industrial control simulation with a $1 \% \mathrm{CO}_{2}$ increase per year until quadrupling and stabilized for 300 years at four times the $\mathrm{CO}_{2}$ level. Standard model 2 was run in coupled ocean-atmosphere mode from a present-day simulation with $1 \% \mathrm{CO}_{2}$ increase per year, stabilized at 4 times the $\mathrm{CO}_{2}$ level. Ozone levels were kept constant in the simulations. We analysed 150 years from the standard and extended models for both $1 \mathrm{xCO}_{2}$ and $4 \mathrm{xCO}_{2}$. Again, note that extended model 2 simulates a near surface climate which is close to that of standard model 2 (Fig.1).

We also use model results from the World Climate Research Programme's (WCRP's) Coupled Model Intercomparison Project phase 3 (CMIP3) multi-model dataset (Meehl et al. 2007) and from the Chemistry Climate Model Validation (CCMVal) project (Morgenstern et al. 2009) to test whether our results are similar to those in other climate models. The following IPCC models were used to make a multimodel ensemble of standard models: INM-CM3.0, IPSL-CM4, UKMO-HadGEM1, MRI-CGCM2.3.2, MIROC3.2(medres), GISS-ER, GFDL-CM2.1, GFDL-CM2.0, ECHAM5/MPI-OM, ECHO-G, CNRM-CM3, CGCM3.1. Details of the models and simulations performed can be found at: www-pcmdi.llnl.gov/ipcc/about_ipcc.php. The following CCMVal models were used to make a multimodel ensemble of extended models: CMAM, CNRM-ACM, LMDZrepro, UMSLIMCAT, WACCM, CCSRNIES, SOCOL, UMUKCA-UCAM and EMAC-FUB. CCMVal-Ref-B2 simulations were used which 
include the A1B IPCC scenario. By 2100 the change in ozone in these simulations is small, especially in the northern hemisphere, while the $\mathrm{CO}_{2}$ concentration is approximately doubled so we scale the differences between 2100 and 1960 in the CCMVal results by a factor of two to create an approximate comparison with our $4 \mathrm{xCO}_{2}$ experiment (a similar comparison between IPCC and CCMVal simulations has already been carried out for the southern hemisphere (Son et al. 2008)). A summary of the simulations is given in Table 1.

\section{Changes in Sea Level Pressure}

We simulated a baseline climate and a climate with four times the amount of carbon dioxide in Standard models 1 and 2 and Extended models 1 and 2, as explained above. Climate change in near surface temperature due to increasing levels of greenhouse gases is relatively similar in the standard models with a large increase in surface temperature in almost all regions. At high latitudes, sea level pressure falls in standard models and this is compensated by a broad region of increased pressure across the Atlantic and Pacific in mid latitudes (Fig.2a). However, there is also a broad range of responses in Atlantic sea level pressure in the standard models. In contrast, the differences between each extended model and its corresponding standard model are very consistent across models. Relative to their respective standard model versions, there is a large reduction in sea level pressure across the Atlantic and Pacific that exceeds $4 \mathrm{hPa}$ (Fig. 2b,c). This difference maximises in the Atlantic and Pacific storm track regions and the signal is much larger in winter than summer (not shown), as would be expected for stratospheretroposphere interaction given that the stratosphere is more dynamically active in the winter season (e.g. Boville et al. 1984, Perlwitz and Graf 1995). The effect on the climate change signal of extending the models upwards is very similar in the two models despite their different formulation and the fact that one of the models has an active ocean while the other has prescribed ocean conditions. The larger area of 
significant differences in Model 2 is due to the much longer length of the simulations there (see earlier model description).

\section{Changes in jet stream winds}

Given that the signal is similar in the Atlantic and Pacific storm track regions but is more significant in both models in the Atlantic, we now focus on this region in more detail. As might be expected, differences between the extended and standard models are largest in the stratosphere (Fig.3). There is a strong dipole response in the stratospheric zonal wind and the polar night jet is weakened and shifted equatorward in the extended models 1 and 2 (Fig.3a) as has been observed in other recent experiments on the stratospheric response to climate change, albeit with some variation between models (Huebener et al. 2007, Sigmond et al. 2008, McLandress and Shepherd 2009, Charlton-Perez et al. 2008, Shindell et al. 1999, Butchart et al. 2010. We can attribute the weakening and shifting of the polar night jet to the increase in planetary wave driving and the average strength of the Brewer-Dobson circulation which occurs in response to increasing greenhouse gas amounts in climate models (Butchart and Scaife 2000, Butchart et al. 2010). This change appears to occur through a change in the mean strength of the circulation rather than through a change in the frequency of sudden warmings which shows only a small and statistically insignificant increase. With their lower vertical resolution in the stratosphere, standard models 1 and 2 show a much weaker dipole and even opposite signed changes in the high latitude stratosphere (Fig.3c).

We now use ensembles of different models to test whether the main differences in response to increasing greenhouse gases between our standard and extended models can be found in other models. A similar exercise has recently been carried out for the response to ozone depletion (Son et al. 2008). The multimodel results confirm that the 
response described above is insensitive to model formulation. Figures $3 \mathrm{~b}$ and $3 \mathrm{~d}$ show changes in the ensembles of extended and standard models. These models span a wide range of formulations and a wide range of physical parametrizations for unresolved processes such as gravity wave drag. Despite their different formulations, the multimodel average of extended models shows an almost identical signal to that in our two extended models with a very strong dipolar pattern in the zonal wind. Similarly, the multimodel average of standard models is very similar to the climate change response in our two standard models with a much weaker dipole. Because the extended and standard models have different formulation we can not absolutely attribute the difference between them to stratospheric resolution. However, it does show that there appear to be robust differences between extended climate models and standard models across the range of currently used models.

\section{Changes in baroclinic eddies and storminess}

The zonal wind response to increased greenhouse gases extends coherently from the stratosphere into the upper troposphere where there is a similar dipole structure (Figs 3a,b). Although this extends into the troposphere, changes in surface winds are much smaller than the large changes near the tropopause and climate change therefore mainly affects the vertical shear of the wind across the depth of the troposphere. Along with the regional decreases in sea level pressure this suggests the possibility of a strengthened mid-latitude Atlantic storm track through increased baroclinic instability in the troposphere. To quantify this, we first calculate the change in the Eady growth rate (Eady 1949, Wittman et al. 2004) of the fastest growing baroclinic eddies in the current and potential future climate:

Eady Growth Rate: $\quad \sigma=0.31 \mathrm{fU} / \mathrm{NH}$ 
Here $\mathrm{f}$ is the Coriolis parameter, $\mathrm{U} / \mathrm{H}$ is the vertical shear of the zonal wind over the whole troposphere (surface to $200 \mathrm{hPa}$ ) and $\mathrm{N}$ is the mean static stability over the whole troposphere. Growth rates are calculated at $10^{\circ} \mathrm{W}$ through the centre of the Atlantic anomaly (neighbouring longitudes give similar results).

The response of the mean winds to increasing greenhouse gas amounts in our extended models dramatically changes the growth rate of baroclinic eddies compared to the standard models (Fig.4). In the standard models the latitude of maximum growth rate for baroclinic eddies increases, as has been found in other studies (Yin 2005, Frierson et al. 2007). In contrast, the vertically extended models show increases in the growth rate at mid-latitudes and zero or decreasing growth rate at high latitudes due to the dipole in the zonal wind shear that is coherent with lower stratospheric winds. The consistent southward shift in Eady growth rate in the extended models is striking given that there is a range of responses to increasing greenhouse gases in standard models (Geng and Sugi 2003, Lambert and Fyfe 2006, Pinto et al. 2007) and that storm tracks are currently expected to move polewards (e.g. Yin 2005). Similar changes occur in the CCMVal multimodel ensemble which show a negative change in the northern annular mode index (Morgenstern et al. 2009) so we now focus on our two models in more detail to understand their effect on the troposphere and surface climate.

Such a large increase in Eady growth rate ought to also be visible in the storm track and associated cyclones. To calculate storminess we use a standard measure (Blackmon et al. 1976) of the standard deviation of 2-6 day band passed geopotential height at $500 \mathrm{hPa}$. The climatology of this quantity is shown in Fig.5a which shows maxima in the Pacific and Atlantic storm tracks. The corresponding change in winter storminess is shown in Figure 5, where an increase in mean winter storminess of up to $20 \%$ occurs near western Europe and extends into central Europe, with a decrease to the north and south west. This change in storminess closely matches the change in mean 
sea level pressure in the storm track regions (Fig.2b) which is consistent with the mean climate shift being explained as a change in the storm track. Daily data for model 2 were not available for this study but the similarity of Figures $2 b$ and $2 c$ shows that similar changes occur in both extended models.

Recent observational estimates indicate a discrepancy between recent changes in mid-latitude storminess and the change found in standard models (Wang et al. 2008) which is similar to the pattern of increased storminess in Figure 5b. Furthermore, recent studies of the extended multi-model set used here also conclude that the Northern Annular Mode index decreases in extended models (Morgenstern et al. 2009) which is consistent with the results shown here as the storm tracks move coherently with the NAM. Coupled with the results shown here, the northward migration of the extratropical storm tracks under climate change may be overestimated in standard resolution climate models.

\section{Changes in Rainfall}

The increased storminess in our extended model simulations has a dramatic impact on climate change in winter rainfall. The standard models already show an increase in winter rainfall across Northern Europe with increasing levels of greenhouse gases (Fig.6a,c). However, the two extended models predict a further large increase in rainfall across much of central and western Europe (Fig.6b,d). Again the agreement between the extended models is very good, suggesting that the effect of extending the models upwards is largely independent of model details or ocean-atmosphere coupling. This exacerbates the increase in rainfall across much of Northern Europe, cancels the projected drying of the Iberian peninsula and exacerbates Mediterranean and North African drying. In some smaller regions across northernmost Europe, projected increases in rainfall are reduced. As an example of the potential impact on climate 
projections of extreme events, corresponding changes in the frequency of extreme rainfall are shown from model 1 (Fig. 7). Both the mean and extreme rainfall closely match the pattern of change in storminess and mean sea level pressure, supporting our mechanism that both the rainfall and sea level pressure changes are due to a change in the storm track. The frequency of 1 in 50 daily heavy Winter rainfall events in western Europe $(10 \mathrm{~W}-20 \mathrm{E}$ and $40-55 \mathrm{~N})$ increases by almost twice as much as $\mathrm{CO}_{2}$ increases in extended model 1 than in standard model 1.

\section{Summary and Concluding remarks}

Winter regional climate change may be systematically different in climate models that have a good representation of the middle atmosphere to those that do not. Differences between model formulations mean that we can not absolutely attribute this to resolving the stratosphere alone. However, the models used here show a consistent response to better representation of stratospheric processes and all that entails, despite differing greatly in their formulation of fundamental processes such as atmosphere-ocean coupling, clouds or gravity wave drag. This suggests that although strong sensitivity to formulation has been found in an individual model (Sigmond et al. 2008) the result of extending models upwards (and all that entails) alters the climate change response in a way that is largely independent of such model details. As such, extending models upwards may represent a first-order correction to climate projections for the midlatitudes. Hence, the effects of including the stratosphere may be more robust across models than the basic climate projections themselves.

The mechanism in extended models begins with changes in the Brewer-Dobson circulation that have been found in many extended models (Butchart and Scaife 2000, Butchart et al. 2010). These shift the stratospheric polar night jet southwards, changing the shear in the upper troposphere. These changes then appear to couple with baroclinic 
eddies in the troposphere through a consistent change in baroclinic growth rates, shifting the preferred latitude for growth of eddies, and hence the storm track southwards, thereby increasing mid-latitude storminess. This greatly affects projections of winter winds, rainfall and therefore the likelihood of future flooding (e.g. Dankers and Feyen 2008) in the mid-latitude storm track regions.

\section{Acknowledgements}

We acknowledge discussions with Jeff Knight, Chris Folland, Doug Smith and Sarah Ineson at the Met Office Hadley Centre while carrying out this work. AAS, DF, NB and SH were supported by the Joint DECC, Defra and MoD Integrated Climate Programme - DECC/Defra (GA01101), MoD (CBC/2B/0417_Annex C5). We also acknowledge funding from the EU-project ENSEMBLES (Contr. No. 505539) and the DFG SPP CAWSES / PROSECCO project. Simulations with model 2 were carried out at the DKRZ in Hamburg, Germany. CCSRNIES computations were completed with the super computer at CGER, NIES and supported by the Global Environmental Research Fund of the Ministry of the Environment of Japan (A-071). We acknowledge the modeling groups, the Program for Climate Model Diagnosis and Intercomparison (PCMDI) and the WCRP's Working Group on Coupled Modelling (WGCM) for their roles in making available the WCRP CMIP3 multi-model dataset. Support of this dataset is provided by the Office of Science, U.S. Department of Energy. We acknowledge the Chemistry-Climate Model Validation Activity (CCMVal) for WCRP's (World Climate Research Programme) SPARC (Stratospheric Processes and their Role in Climate) project for organizing and coordinating the model data analysis activity, and the British Atmospheric Data Centre (BADC) for collecting and archiving the CCMVal model output. 
Blackmon, M., L. (1976). A climatological spectral study of the 500mb geopotential height of the Northern Hemisphere, J. Atmos. Sci. 33: 1607-1623.

Boville, B. A. (1984). The influence of the Polar Night Jet on the tropospheric circulation in a GCM, J. Atm. Sci., 41, 1132-1142.

Butchart N., I. Cionni, V. Eyring, T. G. Shepherd, D. W. Waugh, H. Akiyoshi, J. Austin, C. Brühl, M. P. Chipperfield, E. Cordero, M. Dameris, R. Deckert, S. Dhomse, S. M. Frith, R. R. Garcia, A. Gettelman, M. A. Giorgetta, D. E. Kinnison, F. Li, E. Mancini, C. McLandress, S. Pawson, G. Pitari, D. A. Plummer, E. Rozanov, F. Sassi, J. F. Scinocca, K. Shibata, B. Steil, W. Tian (2010): Chemistry-Climate Model Simulations of Twenty-First Century Stratospheric Climate and Circulation Changes Journal of Climate, 23, 5349-5374.

Butchart, N. and Scaife, A. A. (2001). Removal of chlorofluorocarbons through increased mass exchange between the stratosphere and troposphere in a changing climate. Nature, 410, 799-801.

Charlton-Perez, A. et al. (2008). The frequency and dynamics of stratospheric sudden warmings in the $21^{\text {st }}$ century, J. Geophys. Res., 113, D16116, doi:10.1029/2007JD009571.

Cordero, E. C., and Forster, P.M. (2006). Stratospheric variability and trends in models used for the IPCC AR4, Atmos. Chem. Phys., 6, 5369-5380.

Dankers, R. and Feyen, L. (2008). Climate Change Impact on Flood Hazard in Europe, J. Geophys. Res., 113, D19105, doi:10.1029/2007JD009719.

Eady, E. (1949). Long waves and cyclone waves. Tellus, 1, 33-52.

Frierson D.M.W., J. Lu, and G. Chen (2007). Width of the Hadley cell in simple 
and comprehensive general circulation models. Geophys. Res.Lett., 34, L18804, doi:10.1029/2007GL031115.

Geng, Q. and Sugi, M. (2003). Possible change in extratropical cyclone activity due to enhanced greenhouse gases and sulphate aerosols - study with a high resolution AGCM. J. Clim., 16, 2262-2274.

Gillett, N. P. (2005). Climate modelling: Northern Hemisphere circulation, Nature, 437, doi:10.1038/437496a.

Huebener, H. et al. (2007). Ensemble climate simulations using a fully coupled oceantroposphere-stratosphere general circulation model. Phil. Trans R. Soc. A., 365, 20892101.

Lambert, S. J. and Fyfe, J. C. (2006). Changes in winter cyclone frequencies and strengths simulated in enhanced greenhouse warming experiments: results from the models participating in the IPCC diagnostic exercise. Clim. Dyn., 26, 713-728 (2006). Legutke, S., and Voss, R. (1999), The Hamburg atmosphere-ocean coupled circulation model ECHO-G, Technical Report 18, Deutsches Klimarechenzentrum, Hamburg. Martin, G. et al. (2006). The Physical Properties of the Atmosphere in the New Hadley Centre Global Atmospheric Model (HadGEM1): Part I: Model Description and Global Climatology. J. Climate, 19, 1274-1301.

McLandress C. and Shepherd T.G. (2009). Simulated anthropogenic changes in the Brewer-Dobson circulation, including its extension to higher latitudes, J. Clim., 22 , $1516-1540$.

Matsueda, M., R. Mizuta, and S. Kusunoki (2009): Future change in wintertime atmospheric blocking simulated using a 20-km mesh atmospheric global circulation model. J. Geophys. Res., 114, D12114, doi:10.1029/2009JD011919. 
Meehl, G. A., C. Covey, T. Delworth, M. Latif, B. McAvaney, J. F. B. Mitchell, R. J. Stouffer, and K. E. Taylor (2007): The WCRP CMIP3 multi-model dataset: A new era in climate change research,Bulletin of the American Meteorological Society, 88, 13831394.

Morgenstern O. et al. (2010), Review of the formulation of present-generation stratospheric chemistry-climate models and associated external forcings. J. Geophys. Res., 115, D00M02, doi:10.1029/2009JD013728.

Morgenstern, O., H. Akiyoshi, S. Bekki, P. Braesicke, N. Butchart, M. P. Chipperfield, D. Cugnet, M. Deushi, S. S. Dhomse, R. R. Garcia, A. Gettelman, N. P. Gillett, S. C. Hardiman, J. Jumelet, D. E. Kinnison, J.-F. Lamarque, F. Lott, M. Marchand, M. Michou, T. Nakamura, D. Olivie, T. Peter, D. Plummer, J. A. Pyle, E. Rozanov, D. Saint-Martin, J. F. Scinocca, K. Shibata, M. Sigmond, D. Smale, H. Teyssedre, W. Tian, A. Voldoire, and Y. Yamashita, (2009). Anthropogenic forcing of the Northern Annular Mode in CCMVal-2 models, J. Geophys. Res., 115, D00M03, doi:10.1029/2009JD013347.

Murphy, J.M., Sexton, D. M. H., Barnett, D. N., Jones, G. S., Webb, M. J., Collins, M., and Stainforth, D. A. (2004). Quantification of modelling uncertainties in a large ensemble of climate change simulations, Nature, 430, 768-772.

Pawson S., K. Kodera, K. Hamilton, T.G. Shepherd, S.R. Beagley, B.A. Boville, J.D. Farrara, T.D.A. Fairlie, A. Kitoh, W.A. Lahoz, U. Langematz, E. Manzini, D.H. Rind, A.A. Scaife, K. Shibata, P. Simon, R. Swinbank, L. Takacs, R.J. Wilson, J.A. Al-Saadi, M. Amodei, M. Chiba, L. Coy, J. de Grandpre, R.S. Eckman, M. Fiorino, W.L. Grose, H. Koide, J.N. Koshyk, D. Li, J. Lerner, J.D. Mahlman, N.A. McFarlane, C.R. Mechoso, A. Molod, A. O'Neill, R.B. Pierce, W.J. Randel, R.B. Rood, F. Wu, (2000): 
The GCM-Reality Intercomparison Project for SPARC (GRIPS): Scientific Issues and Initial Results. Bull. Amer. Met. Soc., 81, 781-796.

Perlwitz, J. and Graf, H. (1995). The Statistical Connection Between Tropospheric and Stratospheric Circulation of the Northern Hemisphere in Winter, J. Clim., 8, 2281-2295

Pinto J.G., Ulbrich U., Leckebusch G.C., Spangehl T., Reyers M. and Zacharias S. (2007) Changes in the storm track and cyclone activity in three SRES ensemble experiments with the ECHAM5/MPI-OM1 GCM, Clim. Dyn., DOI: 10.1007/s00382007-0230-4.

Ringer, M. A., et al. (2006). The Physical Properties of the Atmosphere in the New Hadley Centre Global Atmospheric Model (HadGEM1): Part II: Global variability and regional climate. J. Climate, 19, 1302-1326.

Scaife, A. A., Butchart, N., Warner, C. D. and Swinbank, R. (2002). Impact of a spectral gravity wave parametrization on the stratosphere in the Met Office Unified Model. J. Atmos. Sci., 59, 1473-1489.

Scaife, A.A., Knight, J.R., Vallis, G. and Folland, C.K. (2005). A Stratospheric Influence on the Winter NAO and North Atlantic surface climate, Geophys. Res. Lett., 32, L18715.

Shaw T.A. and T. G. Shepherd (2008). Raising the Roof, Nat. Geosci., 1, 12-13. Manzini, E., and McFarlane, N.A. (1998), The effect of varying the source spectrum of a gravity wave parameterization in a middle atmosphere general circulation model, $J$. Geophys. Res., 103, 31,523-31,539, doi: 10.1029/98JD02274).

Shindell, D. T., Miller, R. L., Schmidt, G. A., and Pandolfo, L. (1999): Simulation of recent northern winter climate trends by greenhouse-gas forcing. Nature, 399, 452-455, doi:10.1038/20905. 
Sigmond, M., Scinocca, J.,F. and Kushner, P. J. (2008). Impact of the stratosphere on tropospheric climate change, Geophys. Res. Lett., 35, L12706, doi:10.1029/2008GL033573.

Solomon, S., et al. Climate Change (2007): The Physical Science Basis. Cambridge Uni. Press, pp996.

Son S.-W., Polvani L.M., Waugh D. W., Akiyoshi H., Garcia R., Kinnison D., Pawson S., Rozanov E., Shepherd T. G., Shibata K. (2008). The Impact of Stratospheric Ozone Recovery on the Southern Hemisphere Westerly Jet, Science, 320, 1486-1489.

Wittman M.A.H., Polvani L.M., Scott R.K., Charlton A.J. (2004). Stratospheric influence on baroclinic lifecycles and its connection to the Arctic Oscillation, Geophys. Res. Lett., 31, L16113, doi:10.1029/2004GL020503.

Yin J.H. (2005). A Consistent Poleward Shift of the Storm tracks in simulations of $21^{\text {st }}$ century climate, Geophys. Res. Lett., 32, L18701, doi:10.1029/2005GL023684. Wang, X.L., Swail, V.R., Zwiers, F., Zhang, X. and Fang, Y. (2008). Detection of external influence on trends in atmospheric storminess and northern ocean wave heights. Clim. Dyn., 32, 189-203.

Fig. 1: Climatological winter sea level pressure in the two standard models (a) and extended climate models (b) used in this study. All quantities are winter means (December-February) and units are $\mathrm{hPa}$.

Fig. 2: Climate change in sea level pressure in standard (IPCC) models (a) and the difference between the extended and standard versions of model 1 and model $2(\mathbf{b}, \mathbf{c})$. All quantities are winter means (December-February) and units are hPa. Statistical significance at the $95 \%$ level of confidence is shown by hatching. For panel a) this is significance from zero using a 2 tailed 
test and the inter-model variability. For individual models 1 and 2 it is calculated using a 2tailed t-test for the difference between extended and standard models.

Fig. 3: Climate change in zonal winds from $1 \mathrm{xCO}_{2}$ to $4 \mathrm{xCO}_{2}$ climate in extended models (a, b) and standard models (c, d). Panel a shows the average of extended models 1 and 2. Panel b shows the average of 8 extended model simulations from the CCMVal project. Panel $\mathbf{c}$ shows the average of standard models 1 and 2. Panel $\mathbf{d}$ shows the average of 12 standard model simulations used in the latest IPCC report. Hatching shows statistical significance at the $95 \%$ level as in Fig.1. The winds are a section near the middle of the Atlantic basin anomaly at 10W (neighbouring longitudes show similar patterns).

Fig.4: The Eady growth rate for baroclinic eddies in the standard (blue) and extended (black) models. The change in the growth rate from $1 \mathrm{xCO}_{2}$ to $4 \mathrm{xCO}_{2}$ climate is plotted. Units are days.

Fig. 5: Climatology and Climate Change in Winter storminess $(\mathbf{a}, \mathbf{b})$ in extended model 1 calculated from daily $500 \mathrm{hPa}$ height data for the DJF season (daily data for model 2 were not available for this calculation). Values are plotted as a percentage of the variability in the control simulation and hatching shows statistical significance at the $95 \%$ level using a t-test.

Fig. 6: Climate change in winter mean rainfall in standard models $(\mathbf{a}, \mathbf{c})$ and the difference between extended and standard models $(\mathbf{b}, \mathbf{d})$. Units are $\mathrm{mm} /$ day and hatching shows statistical significance at the $95 \%$ level using a 2 tailed t-test.

Fig.7: Percentage change in the frequency of extreme rainfall in extended model 1 (daily data for model 2 were not available for this calculation. The very marked similarity between mean rainfall changes and rainfall extremes is easily seen by comparison with Fig.4 for model 1). Extremes here are defined as $98^{\text {th }}$ percentile daily totals at each model grid point. Climate change in standard model 1 (a) and the difference between extended and standard model 1 (b). 
Hatching shows where the change in mean rainfall is statistically significant at the $95 \%$ level according to a t-test and has the same sign as the change in extreme rainfall frequency.

Table 1: Summary of simulations analysed in this study.

a

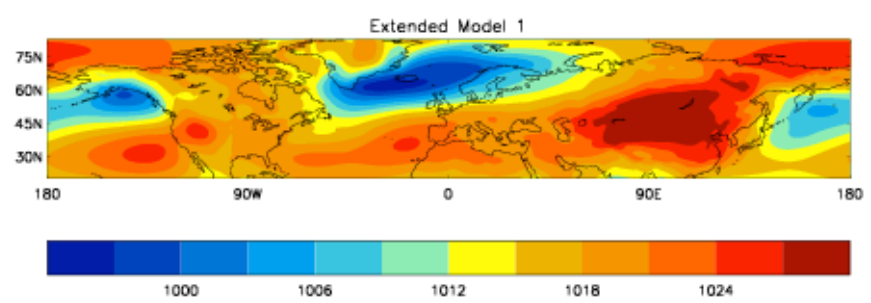

b

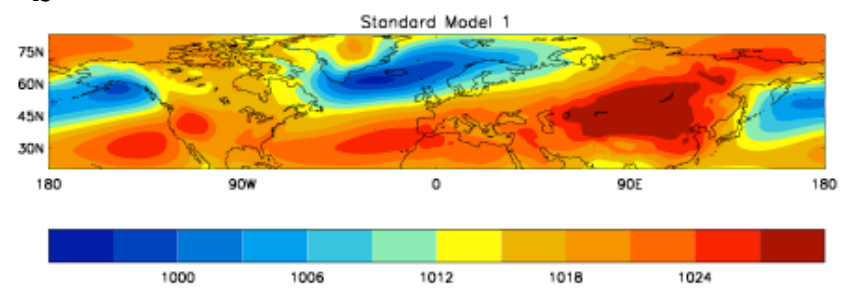

c

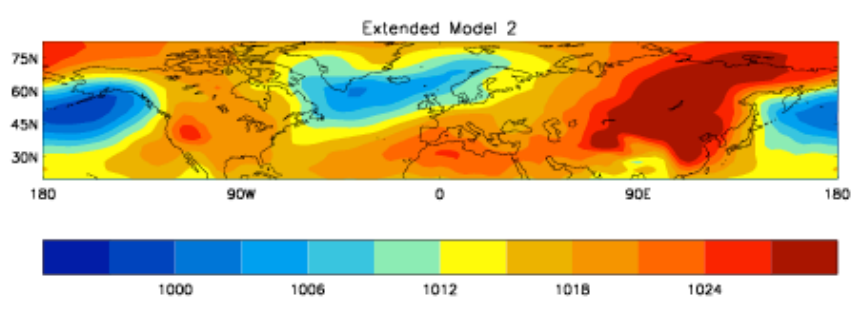

d

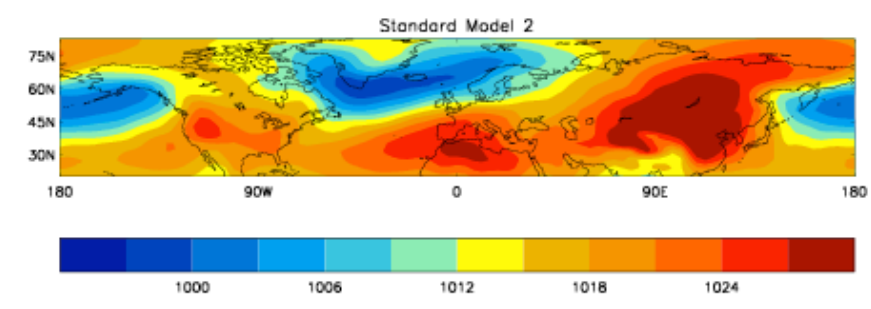


Fig. 1 

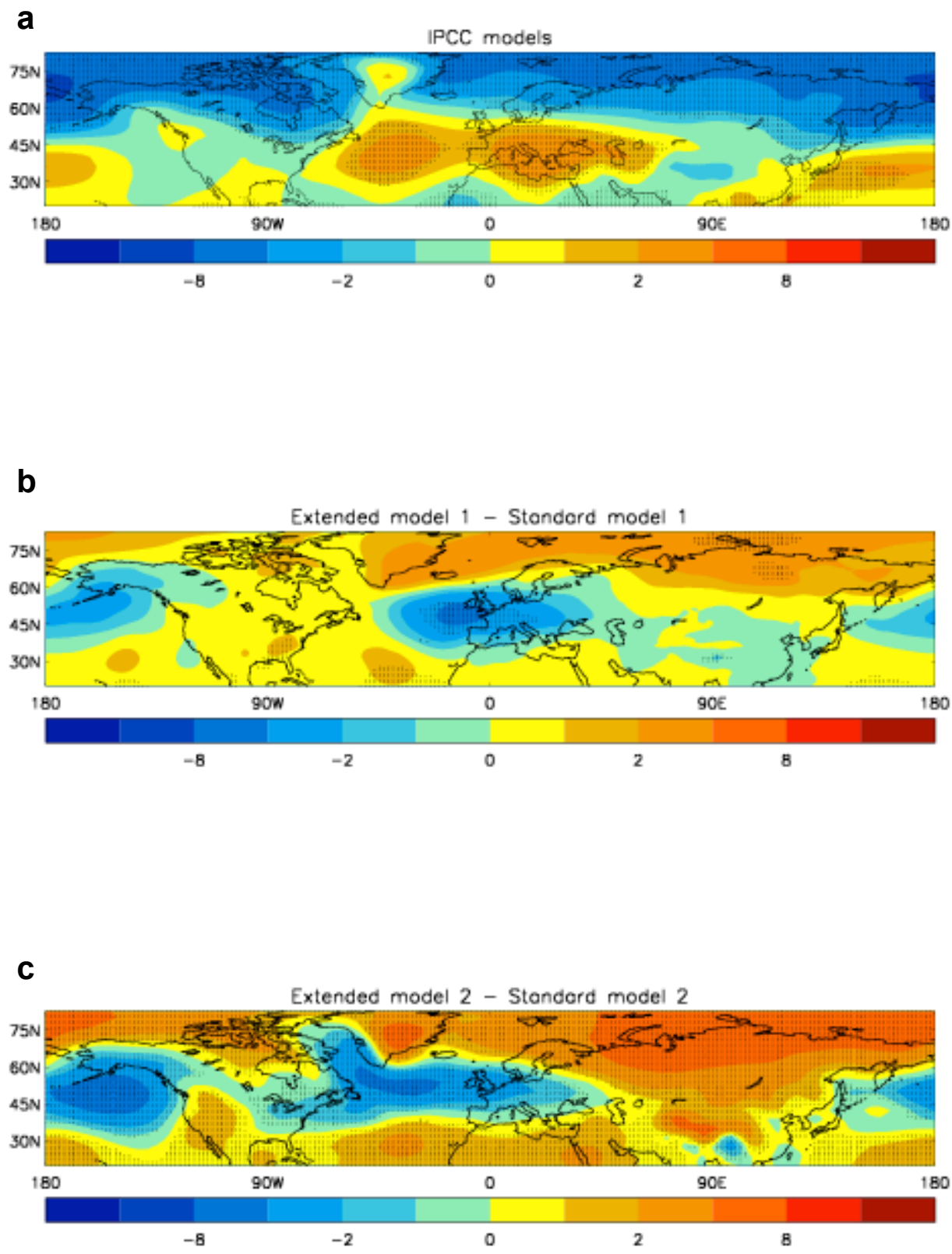

Fig.2 
a

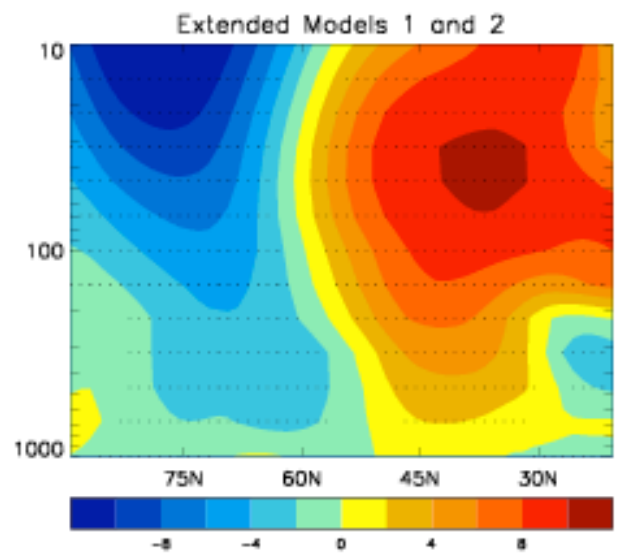

C

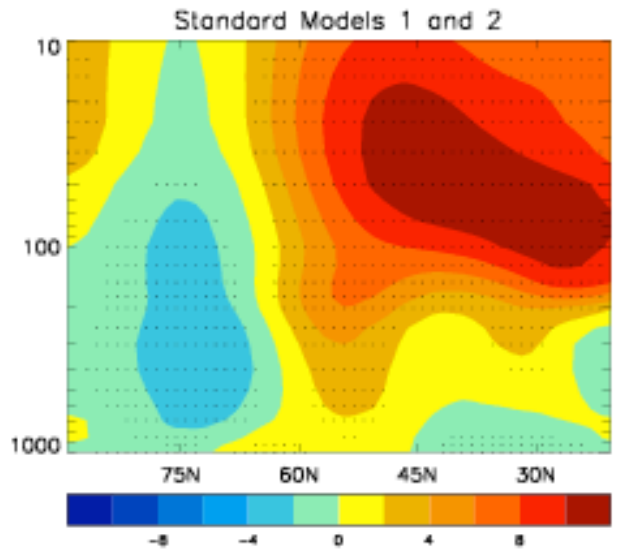

b

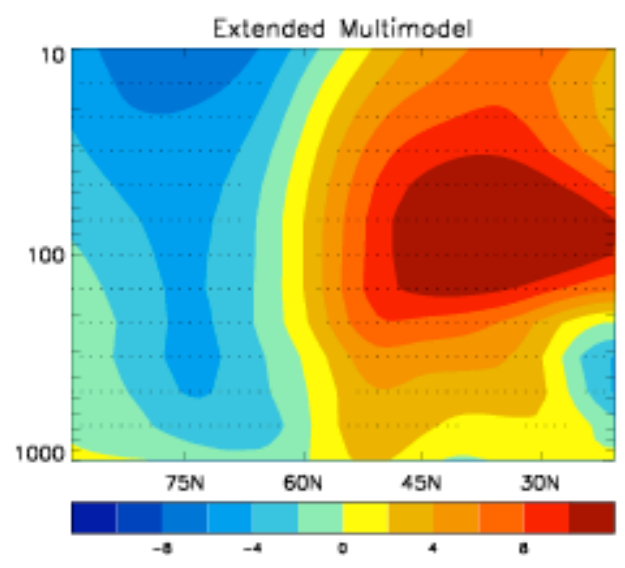

d

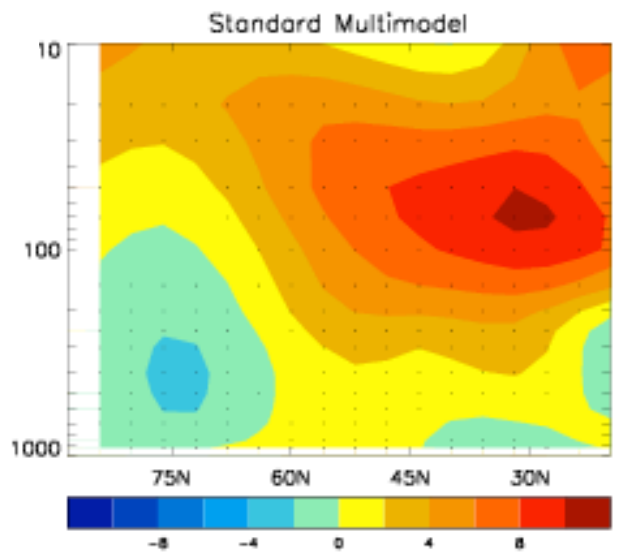

Fig. 3 


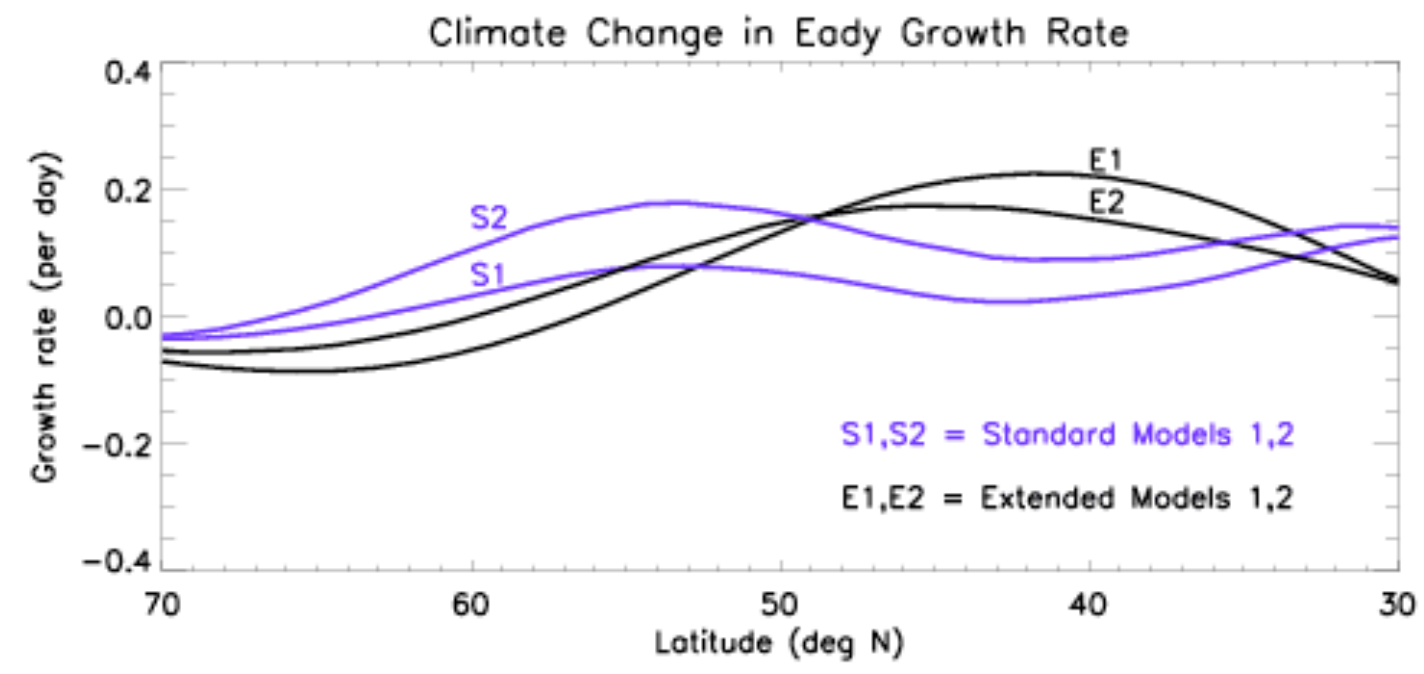

Fig. 4 

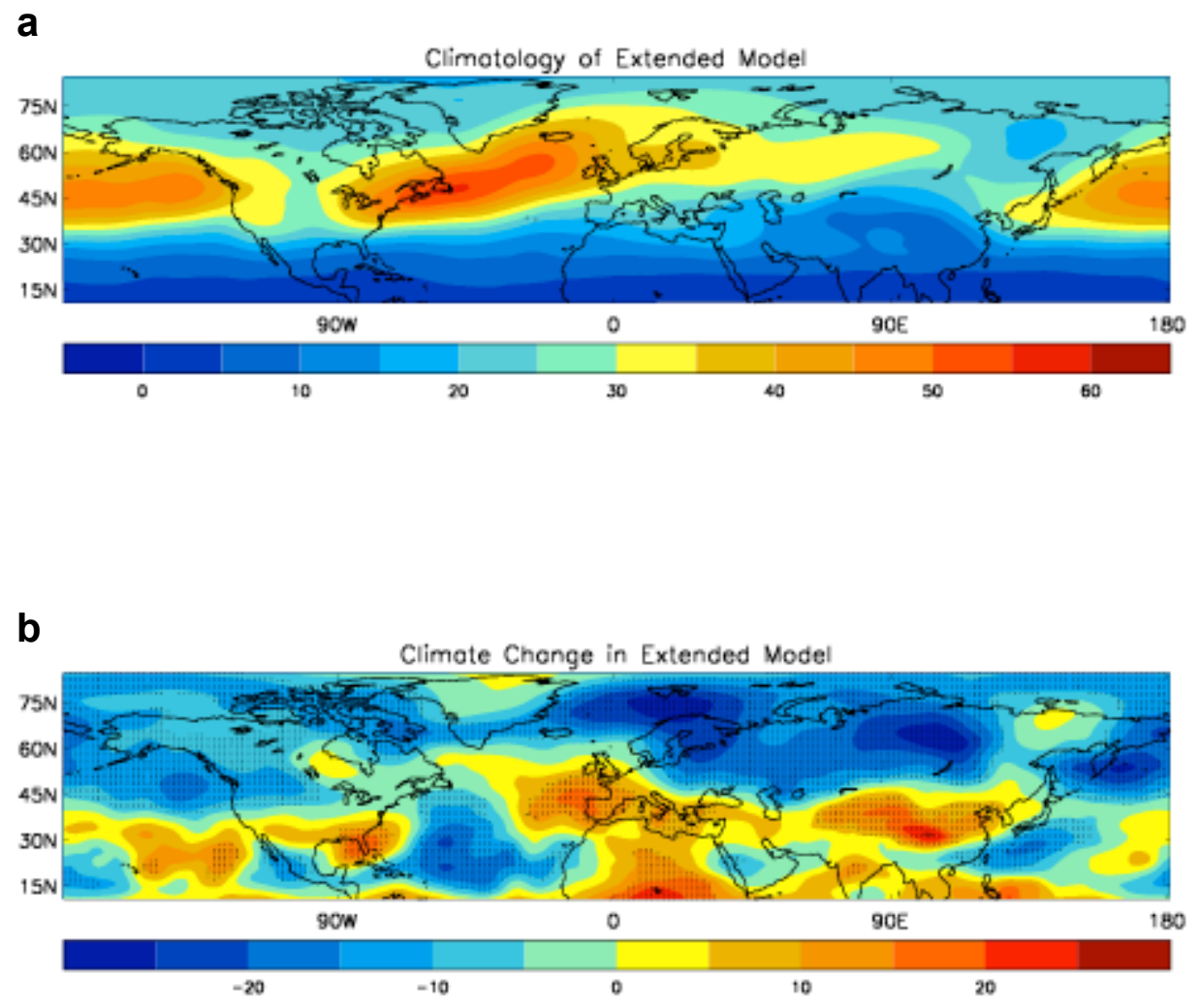

Fig. 5 
a
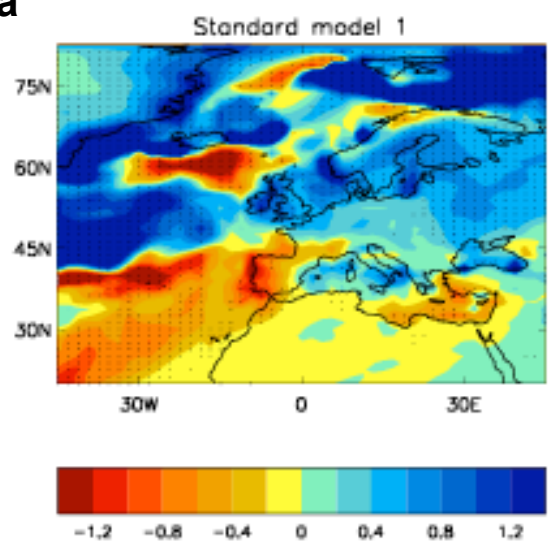

C
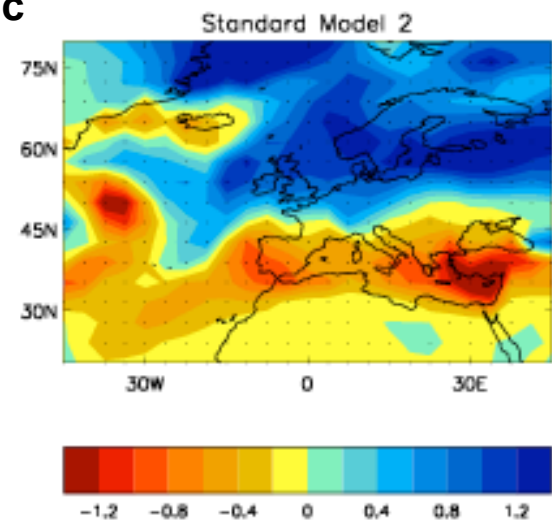

b
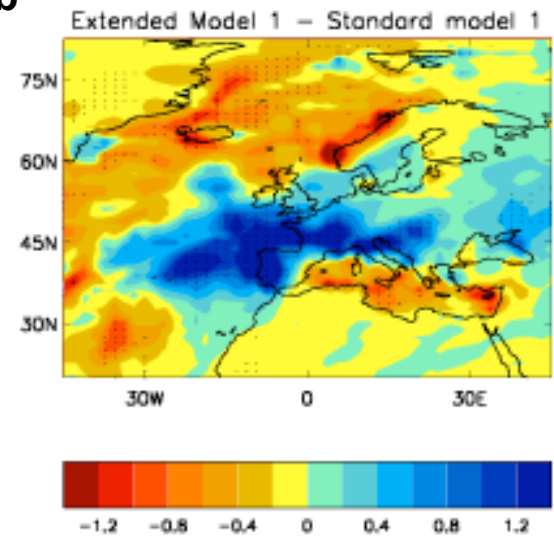

d

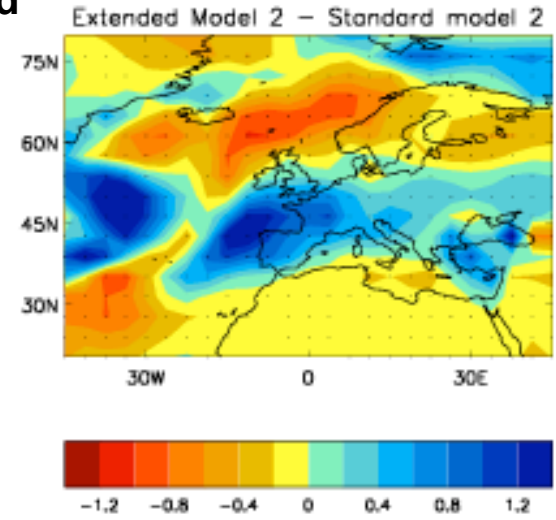

Fig. 6 
a
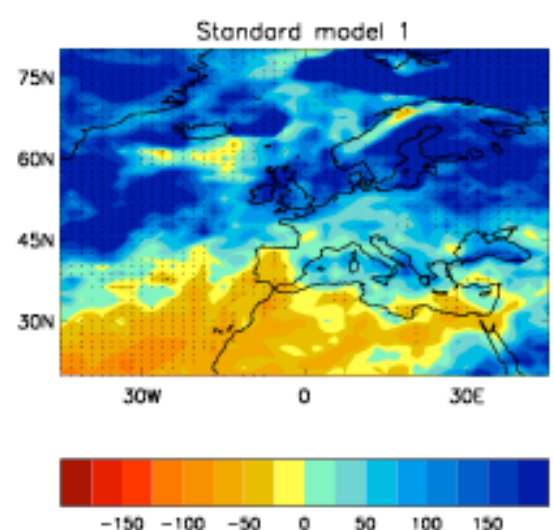

b
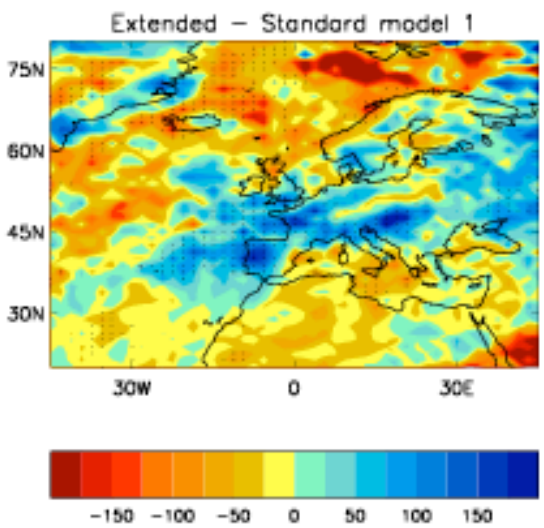

Fig. 7 


\begin{tabular}{|l|l|l|l|l|}
\hline & Control & Experiment & Model Type & $\begin{array}{l}\text { Stratosphere } \\
\text { Resolving? }\end{array}$ \\
\hline $\begin{array}{l}\text { HadGEM } \\
\text { Standard }\end{array}$ & $1 \mathrm{xCO}_{2}$ & $4 \mathrm{xCO}_{2}$ & Atmosphere only & No \\
\hline $\begin{array}{l}\text { HadGEM } \\
\text { Extended }\end{array}$ & $1 \mathrm{xCO}_{2}$ & $4 \mathrm{xCO}_{2}$ & Atmosphere only & Yes \\
\hline ECHOG & $1 \mathrm{xCO}_{2}$ & $4 \mathrm{xCO}_{2}$ & $\begin{array}{l}\text { Coupled Ocean - } \\
\text { Atmosphere }\end{array}$ & No \\
\hline EGMAM & $1 \mathrm{xCO}_{2}$ & $4 \mathrm{xCO}_{2}$ & $\begin{array}{l}\text { Coupled Ocean - } \\
\text { Atmosphere }\end{array}$ & Yes \\
\hline IPCC AR4 & $1 \mathrm{xCO}_{2}$ & $4 \mathrm{xCO}_{2}$ & $\begin{array}{l}\text { Coupled Ocean - } \\
\text { Atmopsphere }\end{array}$ & No \\
\hline CCMVal & $1 \mathrm{xCO}_{2}$ & $2 \mathrm{xCO}_{2}(\mathrm{x} 2)$ & Atmosphere only & Yes \\
\hline
\end{tabular}

Table 1 